\title{
Enhancing University Students' Achievement in Physics using Computer-Assisted Instruction
}

\author{
Christian S. Ugwuanyi ${ }^{1,2} \&$ Chinedu I.O. Okeke ${ }^{3}$ \\ ${ }^{1}$ Postdoctoral fellow, School of Education Studies, Faculty of Education, University of the Free State, Bloemfontein, \\ 9300, South Africa \\ ${ }^{2}$ Department of Science Education, Faculty of Education, University of Nigeria, Nigeria \\ ${ }^{3}$ Host, Professor and Head, School of Education Studies, Faculty of Education, University of the Free State, \\ Bloemfontein, 9300, South Africa \\ Correspondence: Dr. Christian S. Ugwuanyi, Postdoctoral Fellow, School of Education Studies, Faculty of Education, \\ University of the Free State, Bloemfontein, 9300, South Africa.
}

Received: June 22, 2020

doi:10.5430/ijhe.v9n5p115
Accepted: July 16, 2020

Online Published: July 17, 2020

\begin{abstract}
Twenty-first century classrooms have come with a lot of changes in instructional delivery at various levels of education. However, most lecturers in Nigerian universities still adopt the traditional method of instruction not minding the demands of the twenty-first century classrooms. As a result of this, there is a dearth of empirical evidence on the impact of computer-assisted instruction on the students' achievement in physics. This study, therefore, sought the efficacy of computer-assisted instruction (CAI) on students' achievement in physics. A randomized controlled trial experimental design was adopted for the study using a sample of 120 participants. Physics Achievement Test (PAT) was used to collect data for the study. Analysis of covariance was used to analyze the data. It was found that Computer-Assisted Instruction (CAI) had a significant effect on students' achievement in physics at posttest and follow-up assessments. Thus, Physics education lecturers should be trained on how to design and use CAI package for effective twenty-first century classroom instructional delivery in a Nigerian university.
\end{abstract}

Keywords: achievement, computer assisted instruction, enhancing, physics, university students

\section{Introduction}

\subsection{Problem of the Study}

Over the years, the students' achievement in the sciences, most especially in physics has been below expectations (Akanbi et al., 2018; Ugwuanyi et al., 2019a). Students' performance in physics examinations has not been encouraging at different levels of education (Ugwuanyi et al., 2020a). Besides, Erdemir as cited in Ugwuanyi et al. (2020a), found that performance in physics is lower than other science subjects such as biology and chemistry. The implication is that shortly, the nation may not have enough efficient manpower and would have no choice than to rely on the product and efficient manpower from other countries. Azuka (2013) stated that out of the major factors that influence students' achievement, teacher factors appear prominent.

Students' poor performance in physics can be attributed to the lack of teachers' use of innovative teaching strategies in the twenty-first-century classroom (Ugwuanyi et al., 2020a). According to Ugwuanyi et al. (2020a), information communication technology (ICT) has a significant impact on students' achievement, especially in this twenty-first century world. This implies that the method of instruction adopted by the teachers largely determines the achievement of students in mathematics and physics. There is thus an urgent need for a paradigm shift in the methods that the contents of physics are passed on to the students, especially in the twenty-first-century classrooms. The use of Computer system especially Multimedia projection in teaching can be a solution to the poor performance of students in physics. This is buttressed by Idahosa (2003) who opined that since students are very much interested and excited in the use of computer systems, it is necessary for mathematics and physics teachers to catch in the opportunity to use the machine as a teaching aid. Explaining further, Idahosa asserted that computer is highly adaptable in teaching vital parts of mathematics, most especially the elementary parts. It enables the students to grasp very well the major background concepts behind advanced mathematical calculations. 
In the view of Oranu (2006), a well prepared and presented CAI or CAL package helps in the facilitation of the education process since interests of students are generated as they are actively involved in what they view on the screen. The use of multimedia projection, a subset of Information and Communication Technology (ICT), can enhance teaching and learning. Thus, every teacher must be ICT literate in all ramifications (Azare, 2019). Based on the foregoing, the researchers determined the efficacy of the CAI on physics students' achievement within the theoretical framework of Richard Mayer's cognitive theory of multimedia learning.

\subsection{Theoretical Background of the Study}

This study was anchored on Richard Mayer's (1947) cognitive theory of multimedia learning which states that learning becomes effective when it comes from words and pictures than words alone. Mayer believes that deep learning by the students is achieved through sounds and images. Mayer stipulated that auditory and visual channels are important for processing information. According to Mayer, auditory and visual processes influence sensory, working, and long term memory. This theory is related to the present study in that computer-assisted instruction consists of both visual and audio channel which can help the students to understand mathematics and physics concepts. This theory has been successfully utilized by Ejimonye et al. (2020a), Ejimonye et al. (2020b), Hamzat et al. (2017) and Edo (2017) to carry out similar studies.

\subsection{Review of Related Empirical Studies}

A lot of studies have been conducted on the effects of computer-assisted instructions on students' achievement as well as motivation in science and social science subjects. Abidoye and Omotunde (2015), Ayotola and Abiodun (2010), Gambari et al. (2014) and Salisu (2015) found that computer-assisted instruction had a significant effect on students' achievement in different subjects of which physics is not part. Hamzat et al. (2017) found that students who were exposed to computer-aided instructional package had significantly higher achievement scores than those who were not so exposed. Etim et al. (2016) found that computer-aided learning course in waves had a positive effect on student's academic performance. Anigbo and Orie (2018) revealed that Microsoft PowerPoint Instruction Strategy had a significant effect on students' achievement. Ezza, Alhuqail and Elhussain (2019) found that instructional technology significantly enhanced learners' composing skills. Ruzicka and Milova (2019) found that there was a significant effect of video analysis in providing feedback on the process of downhill skiing skills acquisition. Ugwuanyi et al. (2019a) found that flipped classroom instructional technology was effective in enhancing the achievement of physics students at both post-test and follow-up measurements. Ugwuanyi et al. (2019b) found that powerpoint presentation had a significant effect on students' achievement in physics and mathematics. Ugwuanyi et al. (2020a) found that animated powerpoint presentation (PPT) significantly enhanced the achievement of students in physics. Ejimonye et al. (2020a, 2020b) found that the 2D animation technique had a significant effect on students' motivation and achievement in the quantitative/mathematical content of economics respectively. Ugwuanyi et al. (2020b) found that digital game-based learning significantly $(\mathrm{p}<05)$ improved the achievement of primary school pupils at both the post-test and follow-up measures.

The forgoing indicated that computer-based instructional strategies are effective in enhancing students' motivation to learn as well as their achievement in science and social science subjects. However, none of the studies reviewed studied the efficacy of computer-assisted instruction on University students' achievement in physics in Nigeria and this gap in literature necessitated this study. In the twenty-first century era, computer instructions are better practiced at higher education level to enable the students to acquire the skills of independent learning. Besides, the present COVID-19 pandemic has necessitated a paradigm shift in the method of instruction, especially at the higher education level. Other countries of the world most especially the developed countries have fully integrated various parts of information and communication technology into their education system, but such is lacking in developing countries like Nigeria. Hence, the study determined the efficacy of CAI on Nigerian university students' achievement in physics. The researchers hypothesized that CAI would have a significant impact on students' achievement physics.

\section{Methods}

\subsection{Design of the Study}

A randomized controlled trial (RCT) experimental design was used for the study. RCT experimental design sought to measure and compare the outcomes after the participants have received the interventions. This study design has been used by Nwokeoma et al. (2019), Onyishi et al. (2020), Ugwuanyi et al. (2020c), Ugwuanyi et al. (2020d), Ede et al. (2020) to carry out similar studies. 


\subsection{Ethical Considerations}

University of Nigeria committee on research ethics approved this study through its institutional review board. The participants were served informed consent forms to fill and sign before the recruitment process. The researchers ensured the anonymity of the participants' information throughout the research.

\subsection{Participants}

A sample of 120 participants was used for the study. Purposive sampling technique was used in selecting participants in schools that have computer laboratories in Enugu State, Nigeria.

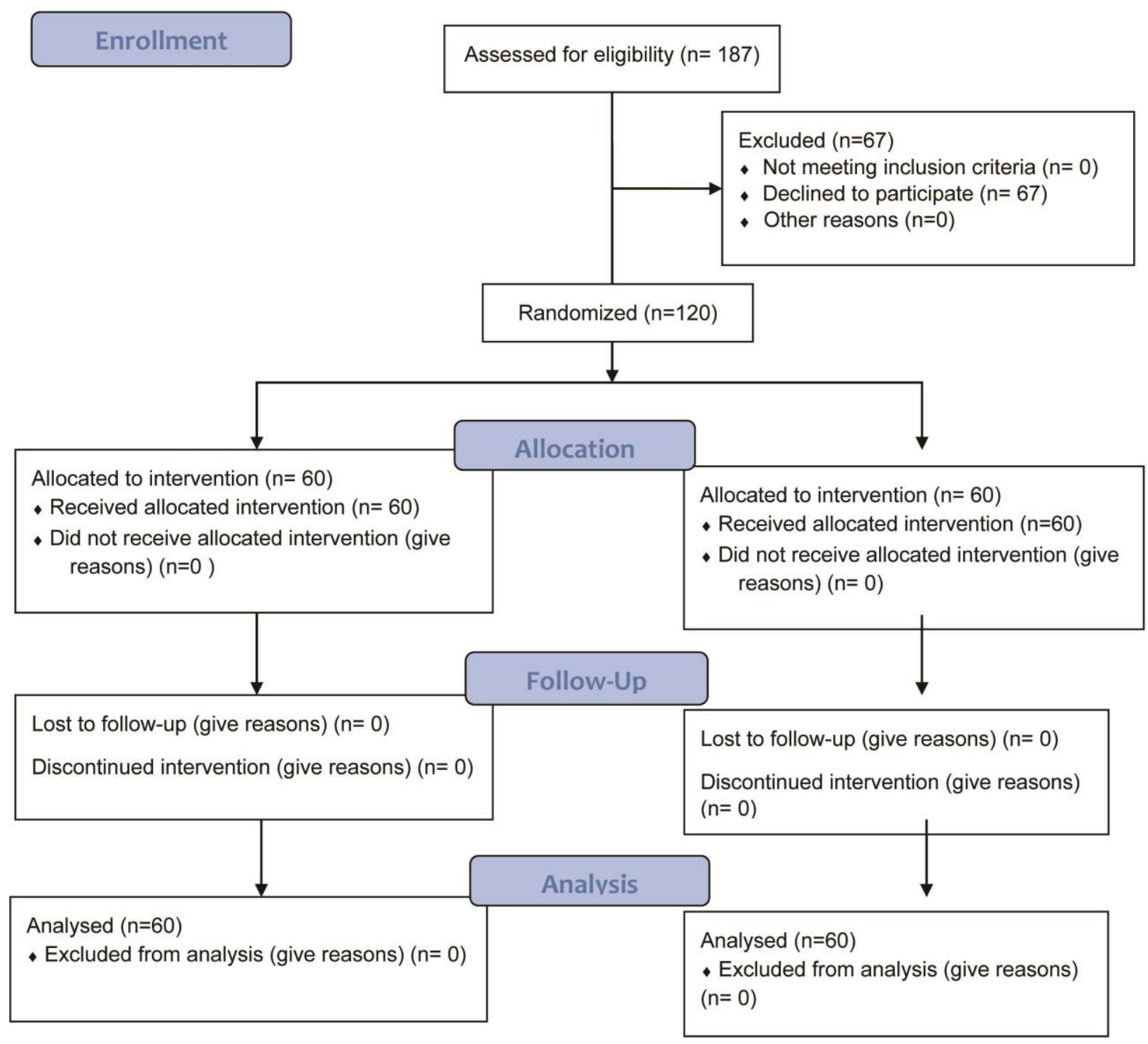

Figure 1. Flow Diagram of the Sampled Participants 
Table 1. Demographic characteristics of the participants

\begin{tabular}{lllll}
\hline Variables & Categories & $\begin{array}{l}\text { Experimental } \\
\text { group }\end{array}$ & Control Group & Total \\
\hline Gender & Male & $28(46.67 \%)$ & $26(43.33 \%)$ & $54(45.00 \%)$ \\
& Female & $32(53.33 \%)$ & $34(46.67 \%)$ & $66(55.00 \%)$ \\
& Total & $\mathbf{6 0}(100 \%)$ & $\mathbf{6 0}(100 \%)$ & $\mathbf{1 2 0}(100 \%)$ \\
Location & Urban & $36(60.00 \%)$ & $32(53.33 \%)$ & $68(56.67 \%)$ \\
& Rural & $24(40.00 \%)$ & $28(46.67 \%)$ & $52(43.33 \%)$ \\
& Total & $\mathbf{6 0}(100 \%)$ & $\mathbf{6 0}(100 \%)$ & $\mathbf{1 2 0}(100 \%)$ \\
\hline
\end{tabular}

\subsection{Measures}

PAT consists of 50-item multiple-choice questions of response options A, B, C \& D. PAT was developed by the researchers using test-blue print or table of specification to ensure its proper content coverage. Items of PAT were generated from some contents of PHY 101 - Introduction to Physics I. These contents are force and motion, energy, heat, sound and light. PAT was face validated by three test development experts. The content validity of the PAT was determined using a table of specifications. An internal consistency reliability coefficient of the items of the PAT was estimated as 0.71 using Kuder-Richardson 20 (KR-20) formula, while the estimate of temporal stability was obtained as 0.83 using the Pearson correlation.

\subsection{Procedure}

PAT was administered as a pretest to the two groups to collect baseline data for the study before the commencement of the treatment procedure. After that, the experimental group was exposed to computer-assisted instruction (CAI) while the control group was exposed to the normal talk and chalk method of teaching. The contents of the instruction were drawn from PHY 101 - Introduction to Physics I. These contents are force and motion, energy, heat, sound, and light. The two approaches for the Experimental and Control groups were identical in terms of content, basic instructional objectives, and content of evaluation. The only difference was in the instructional activities. Each of the groups was exposed to a 6-week intervention program using CAI and the normal talk and chalk method respectively. At the end of the treatment, the posttest was administered to the two groups while the follow-up measure was also administered two months after the termination of the treatment. The data collected from the pretest, posttest, and follow-up measures were arranged, cleaned, and subjected to analysis.

\subsection{Computer-Assisted Intervention Program}

The CAI intervention program involved the development of computer-aided instruction on PHY 101 course contents. The instructional package was made of six different lessons on each of the contents of PHY 101 course that were considered for the study. Each lesson was programmed to last for 40 minutes with an additional 20 minutes for self-evaluation and clarification from the teacher. The role of the teacher in the intervention was mainly to guide the students, especially where they had a problem with the learning process.

\subsection{Data Analysis}

The effect of CAI in enhancing the achievement of university students in physics was determined using a mixed-design analysis of variance (ANOVA). The sphericity assumption of repeated-measures ANOVA was tested using Mauchly test of sphericity which was not significant (Mauchly $W=.853, p=.418$ ), implying that the assumption was not violated. The effect size of the treatment was reported using Partial Eta squared. 


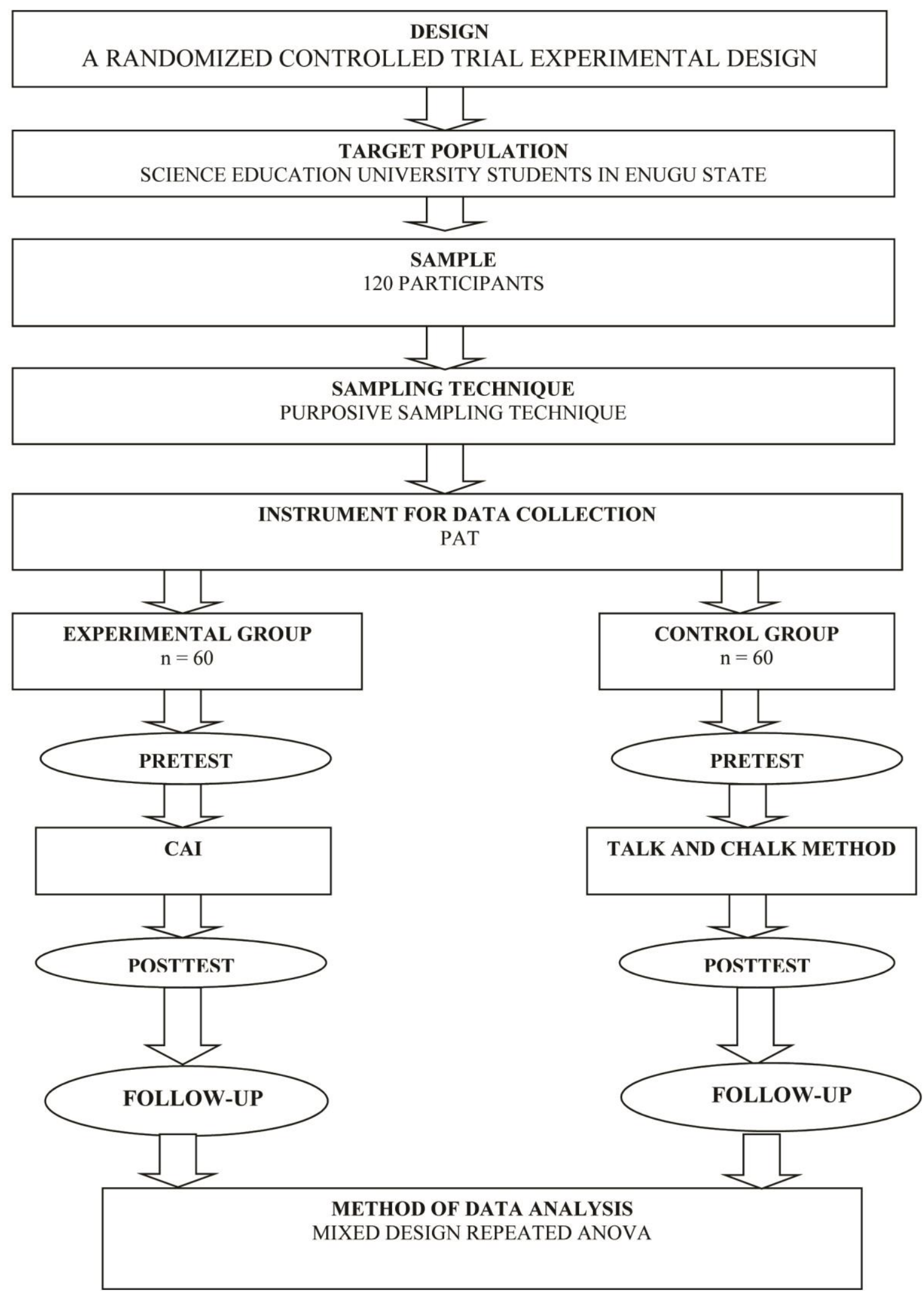

Figure 2. Schematic Representation of the Methodology 


\section{Results}

Table 2. Mean analysis of the students' achievement scores at pretest, posttest, and follow-up

\begin{tabular}{lllll}
\hline & Treatment & $\mathrm{n}$ & Mean & Std. Deviation \\
\hline Pretest & Experimental & 60 & 15.31 & .91 \\
& Control & 60 & 15.42 & .96 \\
Posttest & Experimental & 60 & 42.50 & 4.96 \\
& Control & 60 & 24.15 & 5.16 \\
Follow-Up & Experimental & 60 & 43.48 & 5.24 \\
& Control & 60 & 25.18 & 6.72
\end{tabular}

Table 2 shows that the mean achievement score of the experimental group $(\mathrm{M}=15.31, \mathrm{SD}=.91)$ was almost the same with that of the control group $(\mathrm{M}=15.42, \mathrm{SD}=.96)$ at the prestest. However, at the posttest, the mean achievement score of the participants of the experimental group $(\mathrm{M}=42.50, \mathrm{SD}=4.96)$ was higher than that of the control group participants $(M=24.15, S D=5.16)$. Similarly, the mean achievement score of the participants of the experimental group $(M=43.48, S D=5.24)$ was higher than that of the control group participants at the follow-up $(\mathrm{M}=25.18, \mathrm{SD}=6.72)$.

Table 3. Mixed design repeated analysis of variance for the tests of within-subjects effect and between-subjects effects of the treatment

\begin{tabular}{|c|c|c|c|c|c|c|c|}
\hline \multicolumn{2}{|l|}{ Source } & \multicolumn{4}{|c|}{ Type III Sum } & \multirow[t]{2}{*}{ Sig. } & \multirow[t]{2}{*}{$y^{2}$} \\
\hline & & Tests of With & n-Subject & Effects & & & \\
\hline \multirow[t]{2}{*}{ Time } & Sphericity Assumed & 27182.617 & 2 & 13591.308 & 1191.556 & .000 & .910 \\
\hline & Greenhouse-Geisser & 27182.617 & 1.614 & 16841.869 & 1191.556 & .000 & .910 \\
\hline \multirow[t]{2}{*}{ Time * Treatment } & Sphericity Assumed & 6716.150 & 2 & 3358.075 & 294.404 & .000 & .714 \\
\hline & Greenhouse-Geisser & 6716.150 & 1.614 & 4161.208 & 294.404 & .000 & .714 \\
\hline \multirow[t]{6}{*}{ Error(Time) } & Sphericity Assumed & 2691.900 & 236 & 11.406 & & & \\
\hline & Greenhouse-Geisser & 2691.900 & 190.451 & 14.134 & & & \\
\hline & & \multicolumn{6}{|c|}{ Tests of Between-Subjects Effects } \\
\hline & Intercept & 276058.225 & 1 & 276058.225 & 23336.385 & .000 & .995 \\
\hline & Treatment & 13432.225 & 1 & 13432.225 & 1135.484 & .000 & .906 \\
\hline & Error & 1395.883 & 118 & 11.830 & & & \\
\hline
\end{tabular}

Table 3 revealed that there was a significant difference across the three time measures, $F(2,236)=1191.556, p=$ $<.050, \mathrm{y}^{2}=.910$, and significant difference between groups, $F(1,118)=23336.385, p=<.050, \mathrm{y}^{2}=.995$ in the achievement of university students in physics. The results also showed that there was a significant interaction effect of time and group on the achievement of students in physics, $F(2,236)=294.4040, p=.000, \mathrm{y}^{2}=.714$. This interaction indicated that there was no significant difference between the baseline, and the control group did not improve well on their achievement in physics. However, the mean achievement scores of the university students who were exposed to CAI improved significantly over time, implying that CAI had a significant effect on the achievement of university students in physics. Besides, the effect size of .995 indicated that 99.5 percent increase in the achievement of university students in physics can be attributed to the effect of the CAI package. The nature of the interaction of treatment and time of measures is shown in Figure 3. 


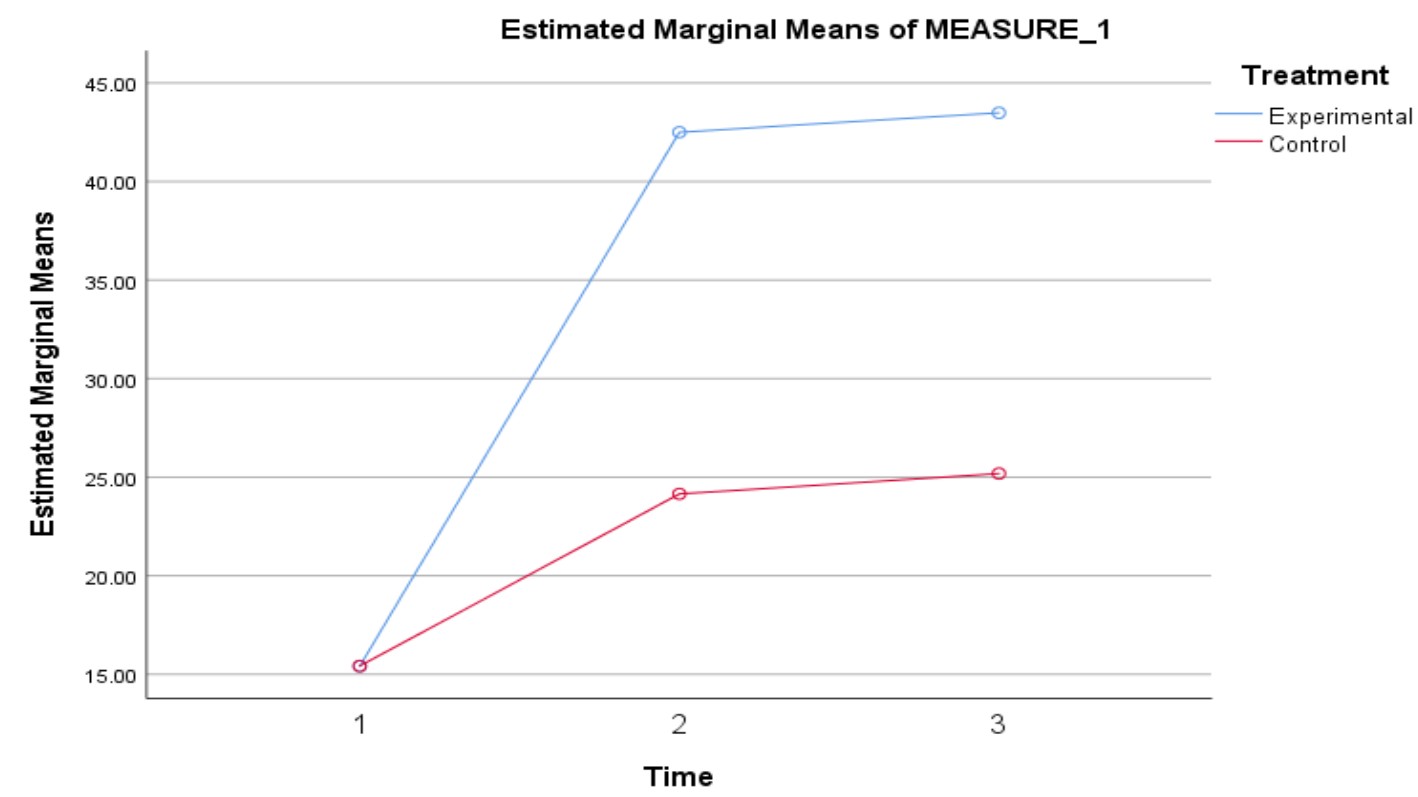

Figure 3. Interaction graph of time and treatment

Table 4. Post Hoc Pairwise Comparisons for the significant difference across the three times

\begin{tabular}{|c|c|c|c|c|c|c|}
\hline \multirow[b]{2}{*}{ (I) Time } & \multirow[b]{2}{*}{ (J) Time } & \multicolumn{3}{|c|}{ Mean Difference } & \multicolumn{2}{|c|}{$\begin{array}{l}\text { 95\% Confidence Interval } \\
\text { Difference }\end{array}$} \\
\hline & & $(\mathrm{I}-\mathrm{J})$ & Std. Error & Sig. & Lower Bound & Upper Bound \\
\hline \multirow[t]{2}{*}{1} & 2 & $-17.908^{*}$ & .339 & .000 & -18.732 & -17.084 \\
\hline & 3 & $-18.917^{*}$ & .424 & .000 & -19.947 & -17.886 \\
\hline \multirow[t]{2}{*}{2} & 1 & $17.908^{*}$ & .339 & .000 & 17.084 & 18.732 \\
\hline & 3 & -1.008 & .525 & .171 & -2.282 & .266 \\
\hline \multirow[t]{2}{*}{3} & 1 & $18.917^{*}$ & .424 & .000 & 17.886 & 19.947 \\
\hline & 2 & 1.008 & .525 & .171 & -.266 & 2.282 \\
\hline
\end{tabular}

Based on estimated marginal means

*. The mean difference is significant at the .05 level.

b. Adjustment for multiple comparisons: Bonferroni.

Table 4 showed that the mean differences for the various pairs of measures are significant at $p<.050$ except for the mean differences between measures 2 and 3,3 and 2 with $p>.050$. Thus, the mean difference for 2 and 3, 3 and 2 did not contribute to the significant effect of time of the exposure of students to the CAI package on their achievement in physics.

\section{Discussion of the Findings}

The findings of the study showed that CAI had a significant impact on university students' achievement in physics. This result goes to portray the interactive nature of CAI which may have activated the interest of the students and thus served as a motivator to learning by the students who participated in the experimental treatment. The improved interest and motivation by the experimental group may have accounted for the enhanced achievement of the students in physics. This result is in line with Usman and Esaduwha (2007) who opined that e-learning is used to enhance and support learning for improvement in students' performance. This finding is also in conformity with Fakae (2014) who opined that e-learning subset such as ICT has greatly improved teaching and learning. This is also in line with Azare (2019) who noted that the use of computers in teaching can best contribute to both teachers' knowledge and teaching effectiveness. 
Buttressing the findings, Etim et al. (2016) found that computer animation learning course in waves had a positive effect on student's academic performance. Falode et al. (2016) found that students taught Agricultural Science through computer animation instructional package performed better than their counterparts taught the same concept with the lecture method. Anigbo and Orie (2018) revealed that Microsoft PowerPoint Instruction Strategy had a significant effect on students' achievement in school. Ezza, Alhuqail and Elhussain (2019) found that instructional technology significantly enhanced learners' composing skills. Ruzicka and Milova (2019) found that the use of video analysis in providing feedback has a positive effect on the process of downhill skiing skills acquisition. Ugwuanyi et al. (2019a) found that flipped classroom instructional technology was effective in enhancing the achievement of students in physics. Ugwuanyi et al. (2019b) found that powerpoint presentation had a significant effect on students' achievement in physics and mathematics. Ugwuanyi et al. (2020a) found that animated powerpoint presentation (PPT) significantly enhanced the achievement of students in physics. Ejimonye et al. (2020a, 2020b) found that the 2D animation technique had a significant effect on students' motivation and achievement in the quantitative/mathematical content of economics respectively. Ugwuanyi et al. (2020b) found that digital game-based learning significantly $(\mathrm{p}<.05)$ improved the achievement of primary school pupils at both the post-test and follow-up measures. Flipped classroom instructional technique enhanced the achievement and retention of physics students (Ugwuanyi et al., 2020e). Teachers can develop Computer Aided Learning (CAL) and use it to promote understanding of concepts in different subject areas. The researchers have, therefore, contributed to the existing body of knowledge in physics education by proving the efficacy of CAI in enhancing the quality of teaching and learning of physics at university level.

\section{Conclusion}

The researchers concluded that CAI is very efficacious in enhancing the achievement of university students in physics. Thus, effective use of CAI by physics education lecturers will enhance students' achievement in physics. Based on that, the researchers recommended among others that:

- Physics Lecturers should use CAI in teaching physics education concepts.

- Both Federal and state governments should equip university computer laboratories for effective implementation of CAI in the teaching of physics concepts.

\section{Acknowledgments}

The researchers appreciate all the participants for this study for their active participation throughout the treatment period.

\section{References}

Abidoye, J. A. \& Omotunde, C. T. (2015). Effects of computer animation package on senior secondary school students' academic achievement in geography in Ondo state, Nigeria. Journal of teaching and teacher education, 3(2). https://doi.org/10.12785/jtte/030202

Akanbi, A.O., Omosewo, E.O., \& Ilorin, B.O.N. (2018). Teachers' characteristics and availability of laboratory as predictors of senior school students' performance in physics in Ilorin, Nigeria. Journal of Teacher Education and Educators, 7(1), 43-55.

American Psychological Association (APA, 2017) Ethical Principles of Psychologists and Code of Conduct: American Psychological Association https://www.apa.org/ethics/code/.

Amoo, S.A. (2002). Analysis of Problem encountered in Teaching and Learning of Mathematics in Secondary Schools. Abacus: Journal of MAN, 27(1), 30-35.

Anigbo, L. C \& Orie, M. J. (2018). Effect of powerpoint instruction on students' academic achievement in computer science (database management system) in Colleges of Education in Rivers State. Computer Engineering and Intelligent Systems, 9(1). www.iiste.org.

Ayotola, A. \& Abiodun, S. (2010). Computer animation and the academic achievement of Nigerian senior secondary school students in biology. Journal of the Research Center for Education Technology (RCET), 6(2), 148-161.

Azare, G. D. (2019). Information and Communication Technology. Foreword for SDGs Workshop, Kaduna: NTI.

Azuka B.F. (2013). Attitude of Secondary Schools' Mathematics Teachers Towards the Teaching of School Mathematics in Nigeria. Journal of Mathematical Science Education, 2(1), June 2013, 181 and 182.

Dike, G. (2013). Mass Failure in WASSCE: Daily Sun www.sunnewsonline.com. Friday, December 20, 2013, $10(2779), 6$. 
Ede, M.O., Anyanwu, J.I., Onuigbo, L.N., Ifelunni, C.O., Alabi-Oparaocha, F.C., Okenyi, E.C., Agu, M.A., Ugwuanyi, L.T., Ugwuanyi, C., Eseadi, C., Awoke, N.N., Nweze, T., \& Victor-Aigbodion, V. (2020). Rational Emotive Family Health Therapy for Reducing Parenting Stress in Families of Children with Autism Spectrum Disorders: A Group Randomized Control Study Moses. Journal of Rational-Emotive \& Cognitive-Behavior Therapy. http://doi.org/10.1007/s10942-020-00342-7

Edo, E. E. (2017). Impact of Computer Animation Learning on students' academic performance in Akwa Ibom College of Education, AFAHA, NSIT . Multidisciplinary Journal of Research Development, 2(26), 1596-974X.

Ejimonye, J.C., Onuoha, J.C., Ugwuanyi, C.S., Eneogu, N.D., Ugwuanyi, B.E \& Ogbuehu, S.N (2020a). Effectiveness of Two-Dimensional Animation Technique in Enhancing Students' Motivation in Quantitative Economics Concepts. International Journal of Future Generation Communication and Networking (IJFGCN), 13(1), 27-38. https://doi.org/10.33832/ijfgcn.2020.13.1.03

Ejimonye, J.C., Ugwuanyi, C.S., Okeke, C.I.O., \& Nwoye, M.N. (2020b). Two-Dimensional Animation and Students' Achievement in Mathematical Economics: Implications for Science Teaching. International Journal of Engineering Research and Technology, 13(6), 1220-1230.

Etim, P.J, Itighise, A.E., \& Ema, I.B. (2016). Use of Educational Animation and Academic Performance of Business Studies Students in Akwa Ibom State . International Journal of Education , 4(8), 1948-547. https://doi.org/10.5296/ije.v8i4.10259

Ezza, E-S., Alhuqail, E. \& Elhussain, S. (2019). Technology-based instructional intervention into an EFL writing classroom. Cypriot Journal of Educational Science, 14(4), 507-519. https://doi.org/10.18844/cjes.v11i4.3904.

Fakae, B. B. (2014). The Computer: An indispensable millennium educational tool. Computer Education Research Journal (CERJ), 1(1), 2.

Falode, O. C., Usman, H., Ilobeneke, S. C., Mohammed, H. A., Godwin, A. J., \& Jimoh, M. A. (2016). Improving secondary school geography students' positive attitude towards map reading through computer simulation instructional package in Bida, Niger State, Nigeria. Bulgarian Journal of Science \& Education Policy, 10(1).

Gambari, A. I., Falode, C. O. \& Adegbenro, D. A. (2014). The effectiveness of computer animation and geometrical instructional model on mathematics achievement and retention among junior secondary school students. European Journal of Science and Mathematics Education, 2(2), 127-146.

Hamzat, A., Bello, G., \& Abimbola, I.O. (2017). Effects of computer animation instructional package on students' achievement in practical biology . Cypriot Journal of Educational Sciences, 4(12), 218-227. https://doi.org/10.18844/cjes.v12i4.2932

Idahosa, G. (2003). Understanding elementary aspects of Mathematics to help in more complex ones. 2003 STAN proceedings.

King-Dow, S., \& Shih-Chuan, Y. (2015). Effective assessments of integrated animations to explore college students' physics learning performances. Procedia - Social and Behavioral Sciences, 176, 588-595. https://doi.org/10.1016/j.sbspro.2015.01.514

Kolawole, S. A. (2012). Information and Communication Technology. Preface for MDG's project, Kaduna: NTI.

Nwokeoma, B.N., Ede, M.O., Ugwuanyi, C., Mezieobi, D., Ugwoezuonu, A.U., Amoke, C., Egenti, N.T., Nwosu, N., Oforka, T.O., Victor-Aigbodion, V., Offordile, E.E., Ezeh, N.E., Eze, C.O., Eluu, P.E., Ugwuanyi, B.E., Uzoagba, N.C., Ugwonna, G.O., Chukwu, C.L., Amadi, K.C., \& Eseadi, C. (2019). Efficacy of prison-based cognitive behavioral rehabilitation intervention on violent sexual behaviors among sex offenders in Nigerian prisons. Medicine; 98(29). (e16103) http://doi.org/10.1097/MD.0000000000016103

Onyishi, C.N., Ede, M.O., Ossai, O.V., \& Ugwuanyi, C.S. (2020). Rational emotive occupational health coaching in the management of police subjective well-being and work ability: A case of repeated measures. Journal of Police and Criminal Psychology, https://doi.org/10.1007/s11896-019-09357-y.

Oranu, P. (2006). Mimeograph on Computer Aided Educational Technology - VTE 562, University of Nigeria Nsukka.

Ruzicka, I. \& Milova, J. (2019). Increasing the efficiency of motor learning with the help of video analysis. Cypriot Journal of Educational Science, 14(4), 723-730. https://doi.org/10.18844/cjes.v11i4.1217 
Salisu, A. (2015). Impact of animated-media strategy on achievement, retention and interest among secondary school geography students in weather concepts, Kastina State, Nigeria (Unpublished Masters thesis). Department of Science Education, Ahmadu Bello University, Zaria, Nigeria.

Ugwuanyi, C.S., Ede, M.O., Onyishi, C.N., Ossai O.V., Nwokenna, E.N, Obikwelu, L.C., Ikechukwu-Ilomuanya, A., Amoke, C.V., Okeke, A.O., Ene, C.U., Offordile, E.E, Ozoemena, L.C., \& Nweke, M.L. (2020c). Effect of cognitive-behavioral therapy with music therapy in reducing physics test anxiety among students as measured by generalized test anxiety scale. Medicine, 99(17),e16406. http://doi.org/10.1097/MD.0000000000016406

Ugwuanyi, C.S., Gana, C.S., Ugwuanyi, C.C., Ezenwa, D.N., Eya, N.M., Ene, C.U., Nwoye, N.M., Ncheke, D.C., Adene, F.M., Ede, M.O., Onyishi, C.N., \& Ossai, V.O. (2020d). Efficacy of cognitive behaviour therapy on academic procrastination behaviours among students enrolled in Physics, Chemistry and Mathematics Education (PCME). J Rat-Emo Cognitive-Behav Ther; https://doi.org/10.1007/s10942-020-00350-7

Ugwuanyi, C. S., Okeke, C. I. O., Nnamani, P. A., Obochi, E. C. \& Obasi, C. C. (2020a). Relative effect of animated and non-animated powerpoint presentations on physics students' achievement. Cypriot Journal of Educational Science. 15(2), 282-291. https://doi.org/10.18844/cjes.v15i2.4647

Ugwuanyi, C.S., Nduji, C.C., Elejere, U.C., \& Omeke, N.E. (2020e). Effect of Flipped Classroom and Think Pair Share Strategy on Achievement and Retention Among Senior Secondary School Physics Students. International Journal of Sciences: Basic and Applied Research (IJSBAR), 52(2), 136-148. https://www.gssrr.org/index.php/JournalOfBasicAndApplied/article/view/11250/5681

Ugwuanyi, C.S., Nduji, C.C., Gana, C.S., Nwajiuba, C.A., Ene, C.U., Okeke, A.O., Eseadi, C., Okeke, C.F. (2019a). Effectiveness of flipped classroom instructional technology model in enhancing students' achievement in physics. International Journal of $u$ - and e- Service, Science and Technology, 12(4), 37-46.

Ugwuanyi, C.S., Okenyi, E.C., Ezema, V., \& Amoke, C. (2020b). Effect of digital game-based learning on achievement of primary school pupils in sciences in Enugu State, Nigeria. Journal of Educational Research on Children, Parents \& Teachers, 1(1), 35-44.

Ugwuanyi, C.S., Ugwuanyi, C.C., Ezenwa-Nebife, D.C., Gana, C., Ene, C., Oguguo, B.C., Ikeh, F.E., Okeke, A.O., Nwoye, M.N., Obi, C.N., Anyaegbu, C. \& Agah, J.J. (2019b). Assessment of the efficacy of information and communication technology tool on achievement of students in physics and mathematics: A case of repeated $\mathrm{m}$ easures. Journal of Engineering and Applied Sciences, 14(13), 4541-4546.

https://doi.org/10.36478/jeasci.2019.4542.4546

Usman, E. O. \& Esaduwha, O. S. (2007). Prospects and Challenges of E-learning in Tertiary Education: Designing and Development of E-learning in Education and Training. STAN Proceedings of the 50th Anniversary Conference. HEBN Publishers Plc.

Usman, K.O. (2002). The need to Retrain in-service mathematics teachers for the attainment of the objectives of Universal Basic Education (UBE). Abacus: The Journal of the Mathematical Association of Nigeria, 27(1), 37-44.

W.A.E.C (2006) West African Senior School Certificate Examination May/June 2006, Chief Examiners' Report Lagos, Nigeria.

W.A.E.C (2007) West African Senior School Certificate Examination May/June 2007, Chief Examiners' Report Lagos, Nigeria.

W.A.E.C (2012) West African Senior School Certificate Examination May/June 2012, Chief Examiners' Report Lagos, Nigeria. 